\title{
Structured Text Data Type
}

National Cancer Institute

\section{Source}

National Cancer Institute. Structured Text Data Type. NCI Thesaurus. Code C95683.

A data type comprised of structured text. 